\title{
Incidence and Prognostic Value of Known Genetic Aberrations in Patients with Acute Myeloid Leukemia - a Two Year Study
}

\author{
Incidencia a prognostický význam známych genetických aberácií \\ u pacientov s diagnózou akútnej myeloblastovej leukémie - \\ dvojročná štúdia
}

\author{
Vaskova J. ${ }^{1}$, Dubayova K. ${ }^{1}$, Cakanova G. ${ }^{1}$, Luckova I. ${ }^{1}$, Bochova I. ${ }^{1}$, Novotna G. ${ }^{1}$, Sabo J. ${ }^{2}$, Palasthy S. ${ }^{3}$, \\ Tothova E. ${ }^{2}$, Stecova N. ${ }^{4}$, Karabinos A. ${ }^{1}$ \\ 'SEMBID, s.r.o., Research Center of Applied Biomedical Diagnostics, Presov, Slovak Republic \\ ${ }^{2}$ Department of Medical Biophysics, Faculty of Medicine, P. J. Safarik University in Kosice, Slovak Republic \\ ${ }^{3}$ Department of Clinical Hematology, J. L. Reiman University Hospital, Presov, Slovak Republic \\ ${ }^{4}$ Department of Hematology and Oncohematology, L. Pasteur University Hospital, Kosice, Slovak Republic
}

\begin{abstract}
Summary
Background: In this work, we evaluated the incidence and prognostic value of several genetic aberrations in patients with a diagnosis of acute myeloid leukemia (AML). Patients and Methods: We analysed 90 patients: 42 males (mean age 54.5 years) and 48 females (mean age 59 years), with AML. The genetics of all leukemia samples was studied using conventional cytogenetics, the interphase fluorescence in situ hybridisation as well as the standardized RT-PCR protocol. Results: In $34.4 \%$ of patients, we detected at least one of the analysed genetic aberrations, except the CBFB-MYH11, which we did not detect. Translocation t(8;21)/AML1-ETO was found in $4.4 \%$ of patients with a mean age of 45.4 years, while none of these patients was older than 55 years. Translocation $\mathrm{t}(15 ; 17) / P M L-R A R A$ was found in $5.5 \%$ of patients with a mean age of 52.6 years and an almost equal distribution between younger and older patients. The $M L L$ gene rearrangements were found in $6.6 \%$ of patients, the $-5 / 5 q-$ and/or $-7 / 7 q-$ aberrations in $7.7 \%$ of patients, while the most frequent genetic abnormality in our study was trisomy 8 (10\%). Moreover, we found a favorable clinical outcome in patients expressing fusion genes AML1-ETO or PML-RARA in contrast to an adverse clinical outcome with few remissions and death in AML patients with $M L L,-5 q /-5$ and $-7 q / 7-$. Finally, an intermediate prognosis was found in patients with trisomy 8. Conclusion: In this study, we found a good congruence with published literature on the incidence and prognostic value of several well established AML-associated genetic aberrations. This simple genetic-based classification system helps us to identify patients with a favorable, intermediate or unfavorable prognosis and to treat them with the best currently available therapy. However, analysis of new genetically defined abnormalities in AML is necessary for development of better therapeutic strategies and/or diagnostics.
\end{abstract}

Key words

acute myeloid leukemia - genetic aberrations - fusion genes - cytogenetics - incidence clinical outcome
This study was supported by the European Regional Development grant OPVaV-2009/2.2/05-SORO (ITMS code: 26220220143).

Táto práca bola podporená grantom z Európskeho Regionálneho Rozvoja OPVaV-2009/2.2/05-SORO (ITMS kód: 26220220143).

The authors declare they have no potential conflicts of interest concerning drugs, products, or services used in the study.

Autoři deklarují, že v souvislosti s předmětem studie nemaji žádné komerční zájmy.

The Editorial Board declares that the manuscript met the ICMJE "uniform requirements" for biomedical papers.

Redakční rada potvrzuje, že rukopis práce splnil ICMJE kritéria pro publikace zasilané do biomedicínských časopisů.

MUDr. Anton Karabinos

SEMBID, s.r.o.

Research Center of Applied

Biomedical Diagnostics

Masarykova 16

08001 Presov

Slovak Republic

e-mail: sembid.pp@gmail.com

Submitted/Obdržané: 15. 10. 2013

Accepted/Prijaté: 29. 1. 2015

http://dx.doi.org/10.14735/amko2015278 


\begin{abstract}
Súhrn
Východiská: V uvedenej práci sme sa zamerali na výskyt a prognostickú hodnotu niekol'kých významných genetických markerov u pacientov s diagnózou akútnej myeloblastovej leukémie (acute myeloid leukemia - AML). Pacienti a metódy:Vyšetrených bolo 90 pacientov s AML: 42 mužov (priemerný vek 54,5 rokov) a 49 žien (priemerný vek 59 rokov). Genetická analýza leukemických vzoriek bola realizovaná pomocou konvenčnej cytogenetiky, interfázovej fluorescenčnej in situ hybridizácie ako aj štandardizovaného RT-PCR protokolu. Výsledky:V 34,4 \% pacientov sme zistili aspoň jeden z analyzovaných genetických markerov s výnimkou translokácie CBFB-MYH11, ktorú sme nezaznamenali. Translokácia t(8;21)/AML1-ETO bola zachytená v 4,4 \% pacientov s priemerným vekom 45,4 rokov, pričom žiadny z týchto pacientov nebol starší ako 55 rokov. Translokácia t(15;17)/PML-RARA bola potvrdená v $5,5 \%$ pacientov s priemerným vekom 52,6 rokov a takmer rovnakým podielom mladších a starších pacientov. Prestavby $M L L$ génu boli potvrdené $v 6,6 \%$ pacientov, aberácie typu $-5 / 5 q-$ a/alebo $-7 / 7 q-$ zachytené $v$ 7,7 \% pacientov, pričom najčastejšou genetickou abnormalitou v našej štúdii bola trizómia chromozómu 8 (10 \%). Navyše sme zistili priaznivý klinický priebeh u pacientov exprimujúcich fúzne gény AML1-ETO, alebo PML-RARA na rozdiel od nepriaznivého klinického priebehu u pacientov s prestavbami $M L L$ génu a deléciami $-5 q /-5$ a $-7 q /-7$. U pacientov s potvrdenou trizómiou chromozómu 8 pozorujeme stredne dobrú prognózu. Záver: Zistili sme súlad medzi našími a publikovanými výsledkami v incidencii a prognostickej hodnote niekolkých dobre definovaných genetických aberácii asociovaných s AML. Táto jednoduchá geneticky-orientovaná klasifikácia nám pomáha rozdelit pacientov na tých s dobrou, strednou a zlou prognózou a zabezpečit im následne najlepšiu momentálne dostupnú liečbu. Avšak, zlý klinický priebeh predovšetkým u pacientov so zlou prognózou, jasne poukazuje na potrebu hladania nových genetických faktorov ochorenia AML pre zabezpečenie vývoja lepších terapeutikých ako aj diagnostických postupov.
\end{abstract}

Klúčové slová

akútna myeloblastová leukémia - genetické aberácie - fúzne gény - cytogenetika - výskyt - klinický priebeh

\section{Backgounds}

Acute myeloid leukemia (AML) is a heterogeneous hematologic disease that results from genetic aberrations in normal hematopoietic stem cells. The incidence of AML is 2.7 per 100,000, while median age at presentation is about 65 years. A clinical expression of this disease is heterogeneous, derived mostly from a bone marrow failure. It includes bleeding, fever, infection, organomegaly and/or lymphadenopathy, which all are frequently present in $A M L$ patients [1]. Moreover, AML is a disease with a high progression rate, leading to death in untreated patients within 2-3 months [2]. However, a slightly better clinical outcome is observed in younger patients without any genetic aberrations or with genetic aberrations associated with a good prognosis, while older patients are less able to tolerate intensive cytotoxic induction and post-remission therapy, have often co-morbid medical illnesses and a poor tolerance of systemic bacterial/fungal infection [3].

The French-American-British (FAB) classification of AML has been used for many years to divide this disease into eight different sub-types (M0-M7) with different morphology and genetics $[1,4]$. A new classification for AML and other myeloproliferations by the World Health Organization (WHO) used many different clinical and laboratory aspects of this disease, including immunophenotyping, cell morphology, cytology and genetics [5].

Both classifications mentioned above use genetic analysis of cells as an important tool to divide AML patients into particular groups with favorable, medium or poor prognosis. One of the most important AML-associated genetic markers is translocation $\mathrm{t}(15 ; 17)$ which produces a fusion gene $P M L-R A R A$ specifically in patients with acute promyelocytic leukemia (APL; the FAB AML sub-type M3). As a result, this specific variant of $A M L$ responds well to the all-trans-retinoic acid-based (ATRA) therapy and is connected with favorable clinical outcome in the majority of patients. The latter holds also for another genetic traslocation $t(8 ; 21)$, which produces an aberrant fusion transcript $A M L 1-E T O$ in about $18 \%$ of the FAB AML sub-type M2. The third well known AML-specific genetic aberration CBFB/MYH11 involves chromosome 16 which could be either inverted (16 inv(16)(p13;q22)) or, less frequently, translocated (t $(16 ; 16)(p 13 ; q 22))$. These aberrations accumulate in the $F A B$ AML sub-type M4Eos and are generally associated with a good prognosis. On the other hand, genetic aberrations of the $M L L$ (mixed lineage leukemia) gene in the locus 11 q23 are associated with a very poor prognosis and affect both children and adults. More than
50 different partners of the $M L L$ gene reported so far are connected to various $F A B$ sub-types of $A M L$, including M0, M4 and M5. Poor prognosis of the AML disease is also indicated by the presence of deletion and/or monosomy of chromosomes $5(-5 /-5 q)$ and $7(-7 /-7 q)$, while a somehow intermediate clinical outcome of AML patients is observed in cases with trisomy $8(+8)$, however, often with a resistance to standard therapy [1-3].

In this work, we analysed the age-dependent incidence of seven known prognostically important genetic markers (t(15;17)/PML-RARA, t(8;21)/AML1-ETO, 16inv (16)(p13;q22)/t(16;16)(p13;q22)/ /CBFB-MYH11, 11q23(MLL), -5/-5q, $-7 /-7 q$ and +8$)$, in a group of 90 patients with AML diseases. Moreover, we evaluated the potential of individual genetic markers to predict a clinical outcome of the AML disease. We discuss these results in the context of previously published literature.

\section{Patients and methods}

\section{Patients}

Between April 2007 and June 2009, we analysed 90 patients: 42 males (with a mean age 54.5 years; range: 24-80 years) and 48 females (with a mean age 59 years; range: $19-87$ years), all with $A M L$ diagnosis. Each diagnosis was established according to the FAB and WHO criteria $[1,4,5]$. The mean time 
of follow-up was 12.3 months (range 1-42 months).

\section{Genetic studies}

The genetics of all leukemia samples was studied centrally in the SEMBID, s.r.o. laboratory. For conventional cytogenetic studies, we used bone marrow (BM) and/or peripheral blood (PB) samples without stimulation. Conventional and G-banding of chromosomes were evaluated according to the International System for Human Cytogenetic Nomenclature, using the standard light microscope Motic BA300. Molecular cytogenetic analyses by interphase fluorescence in situ hybridisation (FISH) were used to detect genetic aberrations $\mathrm{t}(15 ; 17) / P M L-R A R A, \mathrm{t}(8 ; 21) / A M L 1-E T O$, $\operatorname{inv}(16)(\mathrm{p} 13 ; \mathrm{q} 22) / \mathrm{t}(16 ; 16)(\mathrm{p} 13 ; \mathrm{q} 22) /$ /CBFB-MYH11, 11q23(MLL), -5/-5q, -7/-7q and +8 , using the standard fluorescence microscope Olympus BX41. The following FISH-probes were used: LSI AML1-ETO (Vysis), LSI PML-RARA (Vysis), LSI CBFB, inv(16) (Vysis), MLL (11q23) (Kreatech), SE 8(D8Z2) (Kreatech), 5q-(EGR1 5q31; CSF1R 5q33) (Kreatech), 7q-(7q22/7q35) (Kreatech). The procedure for the FISH study is reported elsewhere [6]. The standardized Biomed-1 RT-PCR protocol [7] was used to detect the fusion gene AML1-ETO, PML-RARA and CBFB-MYH11.

\section{Clinical outcome}

A BM aspirate containing fewer than 5\% blasts and a normal maturation of other marrow elements defined complete remission $(C R)$. Other laboratory results were classified by clinicians as a partial remission (PR) (i.e. the failure of the induction therapy to eliminate the disease). Relapse was defined as more than 5\% BM blasts in patients with previously documented CR. From the 90 patients, involved in the study, 24 died due to disease recurrence or progression.

\section{Results}

Age-dependent incidence of known genetic aberrations in AML patients In 31 (34.4\%) of 90 patients involved in this study, we detected at least one of the seven investigated genetic aberrations, described above. Other genetic or cytogenetic aberrations

Tab. 1. The incidence of known genetic aberrations in patients with AML.

\begin{tabular}{|l|c|c|c|c|c|}
\hline Study & $\begin{array}{c}\text { Present } \\
\text { study }\end{array}$ & $\begin{array}{c}\text { Leith } \\
\text { et al [8] }\end{array}$ & $\begin{array}{c}\text { Slovak } \\
\text { et al [9] }\end{array}$ & $\begin{array}{c}\text { Grimwade } \\
\text { et al [10] }\end{array}$ & $\begin{array}{c}\text { Frohling } \\
\text { et al [11]* }\end{array}$ \\
\hline $\begin{array}{l}\text { number } \\
\text { of patients }\end{array}$ & 90 & 164 & 609 & 1,065 & 361 \\
\hline AML1-ETO & $4.4 \%$ & $2 \%$ & $7-9 \%$ & $2 \%$ & $3 \%$ \\
\hline PML-RARA & $5.5 \%$ & n.d. & $4-6 \%$ & $4 \%$ & $3 \%$ \\
\hline CBFB-MYH11 & $0 \%$ & $4 \%$ & $8-9 \%$ & $1 \%$ & $4 \%$ \\
\hline MLL & $6.6 \%$ & n.d. & $6-8 \%$ & $1 \%$ & $3 \%$ \\
\hline$-5 q /-5$ & $4.4 \%$ & $13 \%$ & $5-6 \%$ & $13 \%$ & $16 \%$ \\
\hline$-7 q /-7$ & $5.6 \%$ & $15 \%$ & $8-9 \%$ & $13 \%$ & $14 \%$ \\
\hline+8 & $10 \%$ & $15 \%$ & $8-9 \%$ & $10 \%$ & $13 \%$ \\
\hline
\end{tabular}

${ }^{*}$ investigated patients were over 60 years of age, n.d. - no data

$\mathrm{AML}$ - acute myeloid leukemia

were not evaluated in this study. From the 31 positive patients, 29 (32.2\%) had one and two (2.2\%) had two genetic aberrations.

Translocation $\mathrm{t}(8 ; 21) / A M L 1-E T O$ was found in four $(4.4 \%)$ patients, translocation $\mathrm{t}(15 ; 17) / P M L-R A R A$ in five $(5.5 \%)$ patients, aberrations in the locus $11 \mathrm{q} 23(M L L)$ in six (6.6\%) patients, +8 in nine $(10 \%)$ patients, while aberrations $-5 /-5 q$ or $-7 /-7 q$ were detected in seven (7.7\%) patients (Tab. 1). From the latter seven patients, two $(2.2 \%)$ had $-5 /-5 q$, three (3.3\%) $-7 /-7 q$, while two $(2.2 \%)$ remaining patients had both $-5 /-5 q$ and $-7 /-7 q$ (data not shown). None of analyzed patients had genetic aberrations characterized by the fusion transcript CBFB-MYH11 (Tab. 1).

The mean age of patients with translocation $\mathrm{t}(8 ; 21) / A M L 1-E T O$ was 45.5 years, with translocation $\mathrm{t}(15 ; 17) / P M L-R A R A$ 51.2 years, with aberration $11 \mathrm{q} 23(M L L)$ 52.5 years, with aberration +861.4 years, while the highest mean age of 66.2 years was detected in patients with aberrations of chromosome 5 and/or 7 (Fig. 1A).

When we compared the incidence of analyzed genetic aberrations in the group of patients younger and older than 55 years of age, we detected $\mathrm{t}(8 ; 21) / A M L 1-E T O$ in $10.3 \%$ and $0 \%$ patients, resp., $\mathrm{t}(15 ; 17) / P M L-R A R A$ in $5.1 \%$ and $5.9 \%$ patients, resp., $11 \mathrm{q} 23(\mathrm{MLL})$ in $7.7 \%$ and $5.9 \%$ patients, resp., $-5 /-5 q$ and/or $-7 /-7 q$ in $7.7 \%$ and $11.8 \%$ patients, resp., while aberration +8 was found in $10.3 \%$ of patients younger than 55 years of age and in $9.8 \%$ of older patients (Fig. 1B).

\section{Potential of known genetic} aberrations to predict a clinical outcome of AML patients

In order to evaluate a crude potential of individual genetic aberrations, detected above, and to predict a clinical outcome, 31 patients with AML-associated genetic aberrations (Tab. 1) were analyzed, first for their ability to achieve CR of the disease, second for the presence of a PR/relapse of the disease and finally, for the presence of death (see Patients and methods for details).

CR was achieved in all four (100\%) patients with translocation $\mathrm{t}(8 ; 21) /$ /AML1-ETO, in four (100\%) patients with translocation $\mathrm{t}(15 ; 17) / P M L-R A R A$ (the fifth patient was not included in the calculations presented in Fig. 2 because he died before he was admitted to hospital), in two (33.3\%) patients with aberration 11q23(MLL), in two (28.5\%) patients with aberrations $-5 /-5 q$ and/or $-7 /-7 q$ and in four (44.4\%) patients with aberration +8 (Fig. 2A).

$P R$ and/or a relapse was detected in one $(25 \%)$ patient with $\mathrm{t}(8 ; 21) / A M L 1$ $-E T O$, in none $(0 \%)$ of patients with $\mathrm{t}(15 ; 17) / P M L-R A R A$, in two $(33.3 \%)$ 
patients with $11 \mathrm{q} 23(M L L)$, in three (42.8\%) patients with $-5 /-5 q$ and/or $-7 /-7 q$ and in six (66.6\%) patients with the aberration +8 (Fig. 2B).

Death was detected in one $(25 \%)$ patient with translocation $\mathrm{t}(8 ; 21) /$ /AML1-ETO, in no (0\%) patients with translocation $\mathrm{t}(15 ; 17) / P M L-R A R A$, in all six $(100 \%)$ patients with aberration in $11 \mathrm{q} 23(\mathrm{MLL})$, in all seven (100\%) patients with the aberrations $-5 /-5 q$ and/or $-7 /-7 q$ and in six (66.6\%) patients with aberration +8 (Fig. $2 \mathrm{C}$ ).

Due to the small number of analyzed patients as well as a short time of follow-up, statistical analysis was not performed.

\section{Discussion}

In this work, we used the genetic approach (see Patients and methods) to detect and evaluate the age-dependent incidence as well as a prognostic value of the seven known genetic aberrations (t $(15 ; 17) / P M L-R A R A, \mathrm{t}(8 ; 21) / A M L 1-E T O$, $\operatorname{inv}(16)(\mathrm{p} 13 ; \mathrm{q} 22) / \mathrm{t}(16 ; 16)(\mathrm{p} 13 ; \mathrm{q} 22) /$ /CBFB-MYH11, 11q23(MLL), -5/-5q, -7/-7q and +8$)$ in a group of 90 patients with AML diseases.

In $34.4 \%$ of our patients, we detected at least one of the investigated genetic aberrations, described above, except the CBFB-MYH11 which we did not detect (Tab. 1). A majority (51\%) of our analyzed patients was between $51-70$ years of age, while the remaining patients were between 18-30 (6\%), 31-50 (23\%) and above 71 (20\%) years of age (data not shown). The latter data are in concordance with the published median age of 65 years for AML patients [1].

Translocation $\mathrm{t}(8 ; 21) / A M L 1-E T O$ was found in $4.4 \%$ of patients (Tab. 1) with a mean age of 45.4 years (Fig. $1 \mathrm{~A}$ ), while none of these patients was over 55 years of age (Fig. 1B). The incidence of $t(8 ; 21)$ found in this study is in a range established by previous studies (Tab. 1) [8-11] and also support a previously documented tendency of $\mathrm{t}(8 ; 21)$ to preferentially appear, without any known reason, in younger patients [12].

Translocation $\mathrm{t}(15 ; 17) / P M L-R A R A$ was found in $5.5 \%$ of patients (Tab. 1) with a mean age of 52.6 years (Fig. $1 \mathrm{~A})$, and, in contrast to the above presented $t(8 ; 21)$, almost equally distributed between

A

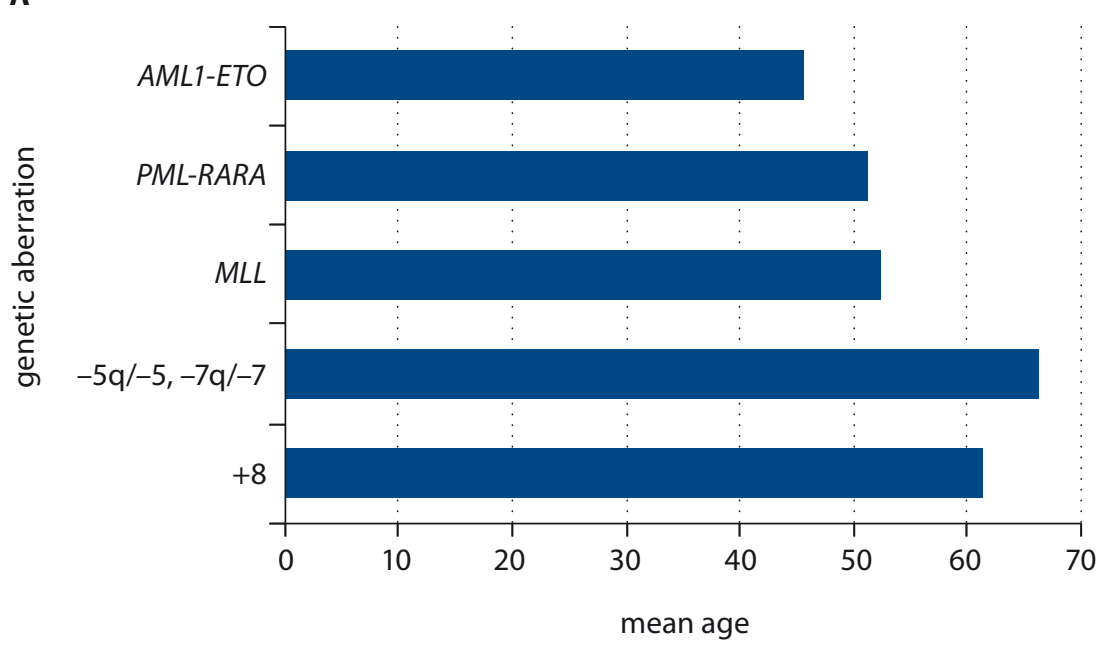

B

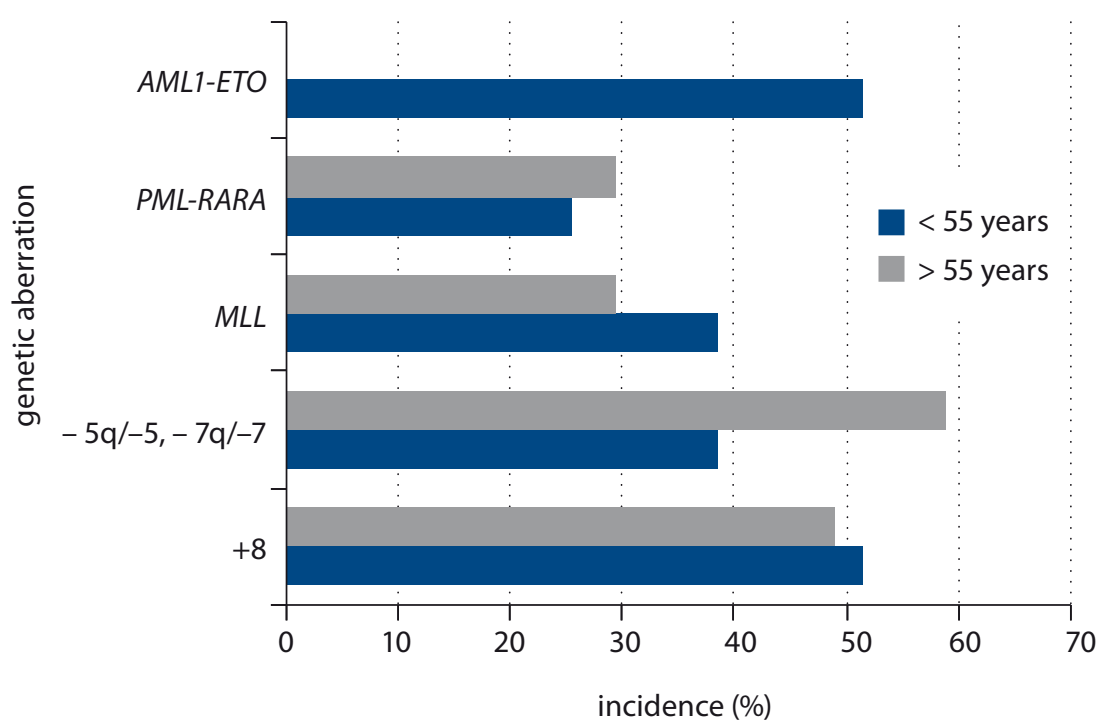

Fig. 1. A. The mean age of $A M L$ patients with individual genetic aberrations.

$B$. Incidence of individual genetic aberrations in AML patients younger or older than 55 years.

AML - acute myeloid leukemia

younger (5.1\%) and older (5.9\%) patients (Fig. 1B). Reported incidences of $t(15 ; 17)$ correlate well with those reported previously (Tab. 1) [8-11].

The known genetic aberrations in the locus $11 \mathrm{q} 23$, comprising the MLL gene, was found in $6.6 \%$ of patients (Tab. 1) with a mean age of 52.5 years (Fig. 1A). However, a slightly higher occurrence was found in younger $(7.7 \%)$ in comparison to older (5.9\%) patients (Fig. 1B). Our reported incidence of MLL is well within a range established by previous studies (Tab. 1) [8-11].

The AML-associated genetic aberrations $-5 / 5 q-$ and $-7 / 7 q-$ was observed in $4.4 \%$ and $5.6 \%$ of our patients, resp. (Tab. 1), with a mean age of 66.3 years (Fig. 1A). In contrast to the MLL-positive patients described above, a slightly higher occurrence was found in older patients $(11.8 \%)$ in comparison to younger (7.7\%) (Fig. 1B). However, the latter incidences were significantly lower 
than those reported in previous studies (Tab. 1) [8-11].

Trisomy 8 was the most frequent genetic abnormality found in this study with incidence of $10 \%$ (Tab. 1), a mean patient age of 61.4 years (Fig. 1A) as well as an almost equal distribution between patients below (10.3\%) and above 55 years of age $(9.8 \%$; Fig. 1B). These results correlate well with those of previous studies (Tab. 1) [8-11] which reported an incidence of the +8 aberration between 8-15\%.

As mentioned above, younger AML patients have better prognosis without any or with favorable genetic aberrations (i.e. AML1-ETO, PML-RARA or CBFB-MYH11). In contrast, a significantly worst prognosis is documented in AML patients over 60 years of age, patients with a secondary AML as well as patients harbouring genetic aberrations associated with poor AML prognosis (i.e. $M L L,-5 q /-5$ or $-7 q /-7$ ) [1-3]. In line with these observations, we detected $C R$ in all our $t(8 ; 21)$-positive patients during the follow-up (Fig. 2A). However, one $\mathrm{t}(8 ; 21)$-positive patient $(25 \%)$ subsequently relapsed (Fig. 2B), while another one died without any previous signs of a disease progression even on the molecular level (Fig. 2C). Thus, some other yet unknown (i.e. genetic) aberrations probably negatively influenced clinical outcome of the latter two patients expressing the prognostically otherwise favorable fusion gene AML1-ETO. In this respect, we noted previously published German-Austrian study which did not observe better survival in a group of treated older patients with $t(8 ; 21)$ in comparison to AML patients with a normal karyotype [11].

The best clinical results with respect to the ability to reach CR (100\%) were observed in the $t(15 ; 17)$-positive patients (Fig. 2A). Moreover, no relapse or death were observed in these patients during follow-up (Fig. 2B, C). These results correlate well with those in previous studies [1] which reported a very good response to the standard ATRA or arsenic-based treatment as well as an achievement of a complete relapse-free remission of the disease in $70-90 \%$ of patients with $t(15 ; 17)$.

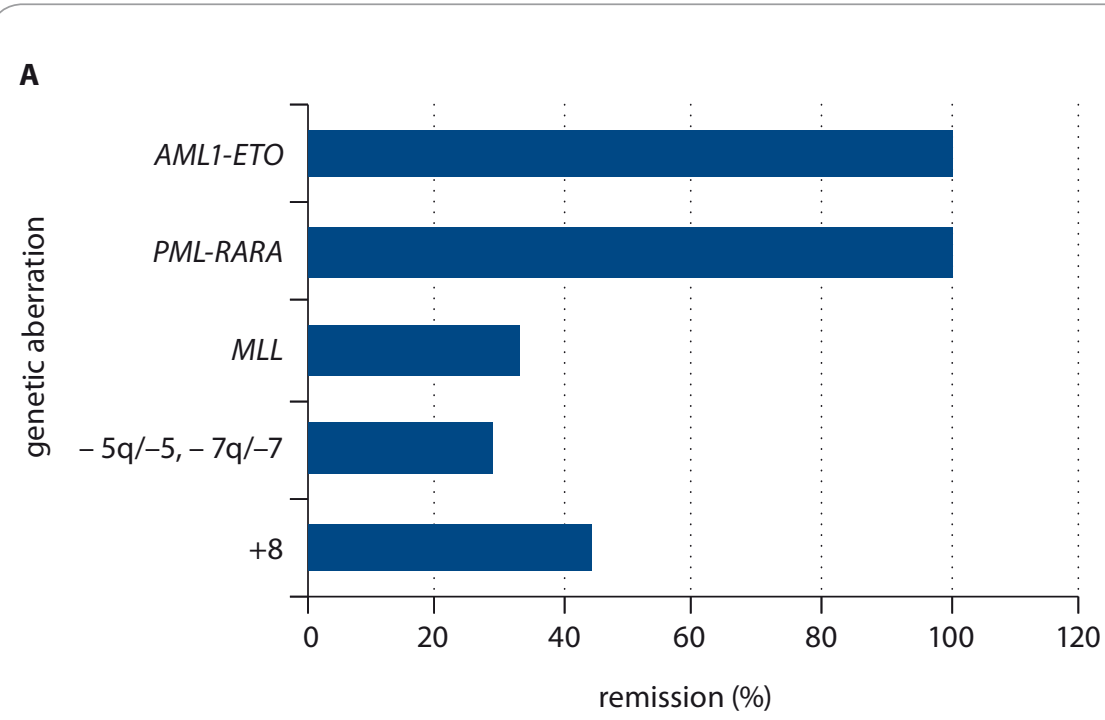

B

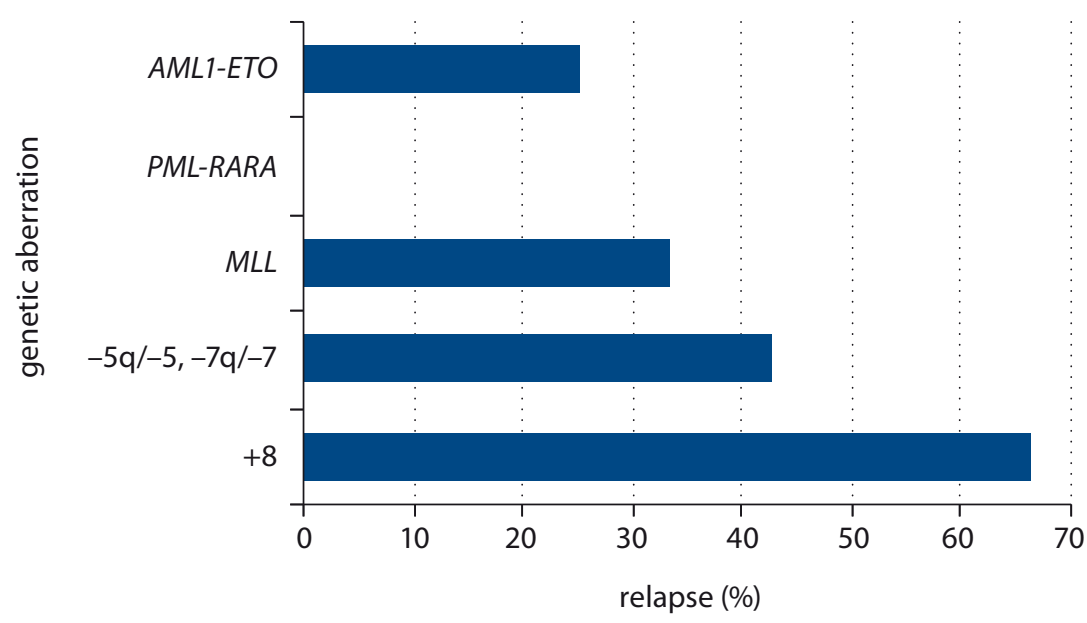

C

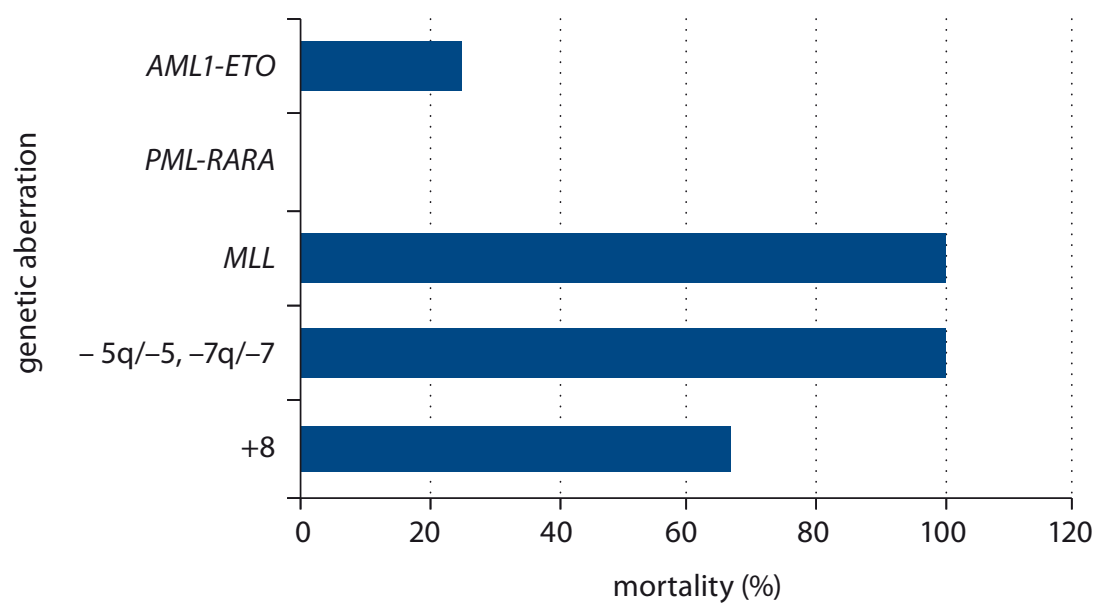

Fig. 2. A. Ability of AML patients with individual genetic aberrations to achieve a remission. $B$. Incidence of relapse in AML patients with individual genetic aberrations.

C. Occurrence of death in AML patients with individual genetic aberrations.

$\mathrm{AML}$ - acute myeloid leukemia 
The MLL genetic aberrations are generally associated with a poor prognosis of the AML disease [1-3]. In line with this characteristic, we observed $C R$ in only two (33.3\%, Fig. 2A) cases in our group of patients with $M L L$, while a high relapse rate and death subsequently occurred in all of them during follow-up (Fig. 2B, C).

Negative prognostic value, comprising only about $40-50 \%$ remissions, resistance to standard therapy and poor survival are associated also with chromosomal aberrations $5 / 5 q-$ or $-7 / 7 q-[1,10]$. In line with these expectations, we observed CR in only $28.6 \%$ (Fig. $2 \mathrm{~A}$ ) of our patients with $5 / 5 q-$ and/or $-7 / 7 q-$, while a high relapse rate and death subsequently occurred in all of these patients during follow-up (Fig. 2B, C).

Finally, in the group with trisomy 8 , we observed CR in $44.4 \%$ of patients (Fig. 2A) and relapse in $33.3 \%$ of them (Fig. 2B). However, $66.7 \%$ of these patients died during the follow-up period (Fig. 2C). These results are fully comparable with the $45-50 \%$ remission rate observed previously $[1,10]$ as well as with the previous finding that the presence of +8 significantly increases risk of death in comparison to patients without this genetic aberration [13].

In summary, we found good congruence with published literature on the incidence and prognostic value of several well-established AML-associated genetic aberrations (see Tab. 1 and text above). This simple genetic-based classification system helps us to identify patients with a favorable (AML1-ETO, PML-RARA, CBFB-MYH11), intermediate $(+8)$ or unfavorable $(M L L$, $5 / 5 q-,-7 / 7 q-)$ prognosis and to treat them with the best currently available therapy [1-4,11-13]. However, a poor clinical outcome, preferentially of the letter group of AML patients, indicates that analysis of new genetically defined abnormalities in AML is necessary for development of better therapeutic strategies and/or diagnostics. Finally, a low incidence of CBFB-MYH11,5/5qand $-7 / 7 q-$ in this study was most likely due to the small number of analyzed patients. We want to explore this in our next study which should also investigate some novel genetic markers, including FLT3 [14], analysed in our laboratory since 2008, or hEag1 - its expression in AML should correlate with increasing age, higher relapse rate and significantly shorter overall survival [15].

\section{References}

1. Jabbour EJ, Estey E, Kantarjian HM. Adult acute myeloid leukemia. Mayo Clin Proc 2006; 81(2): 247-260.

2. Mayer J, Stary J (eds). Leukemie. Praha: Grada Publishing 2002: 392.

3. Erba HP. Prognostic factors in elderly patients with AML and the implications for treatment. Hematology Am Soc Hematol Educ Program 2007; 1: 420-428.

4. Adam Z, Vorlicek J (eds). Hematologie II. Přehled maligních hematologických nemocí. Praha: Grada Publishing 2001: 680
5. Vardiman JW, Thiele J, Arber D et al. The 2008 revision of the World Health Organization (WHO) classification of myeloid neoplasms and acute leukemia: rationale and important changes. Blood 2009; 114(5): 937-951. doi: 10. 1182/blood-2009-03-209262.

6. Giertlova M, Hajikova M, Vaskova J et al. Cytogenetic abnormalities predict treatment-free interval and response to therapy in previously untreated chronic lymphocytic leukemia patients. Neoplasma 2011; 58(1): 82-88.

7. Van Dongen JJ, Macintyre EA, Gabert JA et al. Standardized RT-PCR analysis of fusion gene transcript from chromosome aberrations in acute leukemia for detection of minimal residual disease. Leukemia 1999; 13(12): 1901-1928. 8. Leith CP, Kopecky KJ, Godwin J et al. Acute myeloid leukemia in the elderly: assessment of multidrug resistance (MDR1) and cytogenetics distinguishes biologic subgroups with remarkably distinct responses to standard chemotherapy. A Southwest Oncology Group Study. Blood 1997; 89(9): 3323-3329.

9. Slovak ML, Kopecky KJ, Cassileth PA et al. Karyotypic analysis predicts outcome of preremission and postremission therapy in adult acute myeloid leukemia: a Southwest Oncology Group/Eastern Cooperative Oncology Group Study. Blood 2000; 96(13): 4075-4083.

10. Grimwade D, Walker $\mathrm{H}$, Harrison $\mathrm{G}$ et al. The predictive value of hierarchical cytogenetic classification in older adults with acute myeloid leukemia (AML): analysis of 1065 patients entered into the United Kingdom Medical Research Council AML 11 trial. Blood 2001; 98(5): 1312-1320. 11. Fröhling S, Schlenk RF, Kayser S et al. Cytogenetics and age are major determinants of outcome in intensively treated acute myeloid leukemia patients older than 60 years: results from AMLSG trial AML HD98-B. Blood 2006; 108(10): 3280-3288.

12. Appelbaum FR, Gundacker H, Head DR et al. Age and acute myeloid leukemia. Blood 2006; 107(9): 3481-3485.

13. Wolman SR, Gundacker H, Appelbaum FR et al. Impact of trisomy 8 (+8) on clinical presentation, treatment response, and survival in acute myeloid leukemia: a Southwest Oncology Group study. Blood 2002; 100(1): 29-35. 14. Small D. FLT3 mutations: biology and treatment. Hematology Am Soc Hematol Educ Program 2006; 178-184. 15. Agarwal JR, Griesinger F, Stühmer W et al. The potassium channel Ether á go-go is a novel prognostic factor with functional relevance in acute myeloid leukemia. Molecular Cancer 2010; 9(18): 1-16. doi: 10.1186/1476-4598-9-18.

\section{Informace z České onkologické společnosti}

Zápis ze schůze výboru České onkologické společnosti konané dne 30. 6. 2015 v Brně naleznete na www.linkos.cz. 